\title{
高強度鋼を用いた有孔梁の応力集中を考慮した許容耐力と繰返し性状 ALLOWABLE STRENGTH AND CYCLIC CHARACTERISTIC CONSIDERING OF STRESS CONCENTRATION OF PERFORATED BEAM MADE OF HIGH STRENGTH STEEL
}

\author{
五十嵐規矩夫*, 石 原 直 ${ }^{* *}$, 井畔文彦*** \\ Kikuo IKARASHI, Tadashi ISHIHARA and Fumihiko IGURO
}

\begin{abstract}
This study researches how stress concentration has an effect on cyclic behavior of $\mathrm{H}$-shaped beam with web perforation made of high strength steel "H-SA700". It is examined and compared with the same shaped beam made of "SN400" by cyclic loading tests. Cyclic elastic deformation of H-SA700 increases even under constant-amplitude cyclic loading. This property may amplify the local plasticity near a circular hole. So new yield strength, $Q_{c}$ and $Q_{F}$, by means of elastic theory of stress concentration, are suggested. $Q_{c}$ is a minimum strength when somewehre in a hole edge will be plastic. Similarly $Q_{F}$ is a minimum strength in a minimum section. In addition large deformation behavior of H-SA700 is shown.
\end{abstract}

Keywords : High Strength Steel, Perforated Beam, Stress Concentration, Allowable Strength, Cyclic Characteristic 高強度鋼, 有孔梁, 応力集中, 許容耐力, 繰返し性状

\section{1. 序}

1995 年の兵庫県南部地震以降, 大地震に対して倒壊しないだけで なく, 柱梁を弾性に留め, 建築物の機能を維持できる設計法が提案 されている．制振構造の柱梁に用いることを想定し，新たな高強度 鋼 H-SA700 が平成 16 20 年度の府省連携プロジェクト「革新的構造 材料を用いた新構造システム建築物の研究開発」1)で開発された. H-SA700 は合金元素添加量の低減, 熱処理工程の省略といった製造 技術の確立により, 省資源, 省エネルギー, リサイクルにも適した 鋼材である. 近年様々な実験が行われ, 下記のような研究成果が得 られている.

文献 2)では H-SA700 の基本的な力学性能を明らかにし，従来の SS400 等の鋼材に比べて, 高い降伏比, 小さい破断のび, 低い溶接 性能等の特徵が示されている. 文献 3)では制振構造の柱梁に用いた 場合の繰返し変形性能を明らかにし, 文献 4)では柱梁の梁端部の応 力集中を緩和するダイヤフラムレス型接合部の損傷と性能を評価し ている. 文献 5)，6)では溶接を用いない乾式組立材を用いて, 弾性 横座屈耐力を考察している. また文献 7)では高強度鋼材の弾性保持 を基本とする設計思想から, 大きなウェブ幅厚比を持つ $\mathrm{H}$ 形鋼部材 の使用を想定し，その性能を新たな指標を用いて評価している.

一般に建築構造部材は高力ボルト, ボルト接合部のボルト孔や, 設備配管を通寸ための貫通孔等, 局所的な応力集中を生じるような 断面欠損が存在することが多い。一方で構造計算を行う際は, 断面
欠損のみを考慮して応力集中を無視しているのが通例である。これ は従来の SS400 等が持つ大きな塑性変形能力を前提として応力集中 による局所的塑性化は無視しうるという経験則に基づいていると考 えられる．従来の鋼材に比べて塑性変形能力の小さい高強度鋼につ いて, 許容応力度設計により弾性範囲に留まることが確認されたと しても，部材として断面欠損を免れないとすれば，応力集中による 局所的塑性化の影響を確認しておく必要がある.

これらのことを踏まえて, 本研究では設備配管を通すための貫通 孔を想定した H 形断面有孔梁を扱う。著者らは既にH 形鋼フランジ の継ぎ手材を想定した，応力集中の典型例である円孔付き鋼板の一 軸単調引張載荷及び繰返し載荷実験を行っている ${ }^{8)}$. その中で高強 度鋼 H-SA700 の降伏応力度相当を負担する繰返し載荷における変 形の増加という特性を明らかにし，孔の応力集中によるその特性の 増幅を指摘している．同様のことが曲げせん断力を受ける有孔梁で も起こるのか確かめるべく，降伏耐力を基準とした弾性範囲を中心 に繰返し載荷実験を行った。実験結果より全体の荷重变位挙動に表 れる特性を確認し，ひずみ度分布等から応力集中による局所的塑性 化の様子を明らかにする. さらに孔周辺部の応力集中を弾性理論か らモデル化することで実験結果を再現する．そのモデルより高強度 鋼 H-SA700 を用いた有孔梁の弾性限耐力, 許容降伏耐力を提案寸る. 加えて, 大変形挙動時の繰返し履歴から耐力劣化の様子や最終崩壊 形式についても従来の $400 \mathrm{~N} / \mathrm{mm}^{2}$ 鋼材と比較しながら言及する.
* 東京工業大学大学院理工学研究科建築学専攻 准教授・博士 (工学)

** 独立行政法人建築研究所 主任研究員 - 博士 (工学) （元 国土交通省国土技術政策総合研究所）

*** 東京工業大学大学院建築学専攻 大学院生
Assoc. Prof., Dept. of Architecture and Building Engineering, Tokyo Institute of Technology, Dr. Eng.

Senior Researcher, Building Research Institute, Dr. Eng.

(Former National Institute for Land and Infrastructure Management, MLIT)

Graduate Student, Graduate School, Tokyo Institute of Technology 


\section{H-SA700 有孔梁の弾性挙動と孔周辺のひずみ度分布}

\section{1 実験概要}

図 1 に試験体概要を示す. スチフナより右部の材長 $L$ を試験体区 間とし，片持ち梁形式の繰返し載荷を行う．A-A'の位置から右側を 試験体と寸る。試験体区間をエンドプレートから離し，その間をカ バープレートで補強し応力を緩和することで，フランジへの完全溶 け込み溶接の熱応力の影響, 現在高強度鋼に対してアンダーマッチ ングである溶接材料の影響もなくしている.また孔中心を原点とし て，直交座標系，極座標系を図のように定義する，その孔位置 $l$, 孔径 $\rho$ とウェブ厚 $t_{w}$ を実験パラメータとする.

表 1 に鋼材の機械的性質, 図 2 に代表して JIS1A 号試験片を用い た $9 \mathrm{~mm}$ 厚の素材引張試験結果を示す. 鋼材は建築構造用高強度 $780 \mathrm{~N} / \mathrm{mm}^{2}$ 鋼材 H-SA700 と建築構造用圧延鋼材 SN400 を用いる. 降 伏応力度 $\sigma_{y}$ の算出にはそれぞれ $0.2 \%$ オセット值, 下降伏点を用 いている. 表には図 2 の で示寸最大応力度 $\sigma_{u}$, 弾性係数 $E$, 伸び Elng, 降伏ひずみ度 $\varepsilon_{y}$, 降伏比 Y.R. も示している.

表 2 に $Q$ 添字記号の説明と各種耐力計算值を示す. H 形断面有 孔梁は過去から多くの研究が行われ, 文献 9)で加藤らは全塑性耐力 を確保できる梁端から孔中心までの限界距離 $L_{s}$ を提案している. 限 界距離 $L_{s}$ は曲げ-せん断力関係とフィーレンデール効果を考慮した 耐力で孔部断面と梁端部断面の耐力を等しくおく $\left(Q_{e}=Q_{f e}\right)$ ことで導 かれる ${ }^{10)}$. 本試験では孔位置が限界距離より遠い位置にあり, 孔直 径が梁せいの 50\%である H1，S1 を基準試験体とする.H が H-SA700 の試験体，S が SN400 の試験体である. H2, S2 は孔位置を限界距 離より端部に近くし，H3，S3 は孔直径を梁せいの $60 \%$ にすること で限界距離が長くなり, 孔位置が限界距離より端部に近くなってい る. H4，S4 はウェブを薄くし，孔位置は限界距離より遠いが，せ 儿断降伏が先行する。 なお文献 9)では限界距離が適用される有孔梁 についてせん断降伏が先行する場合は適用外としている．H5 は H1 と同断面の無孔試験体である.

図 3 に載荷プログラムを示す. 図中の基準耐力 $Q_{a}$ の值は表 2 中に 下線付き太字で示す。この值は一般的な構造計算で考えられる耐力 の最小值であり, $\mathrm{H} 3$ と $\mathrm{H} 4, \mathrm{~S} 4$ は孔断面ウェブのせん断降伏耐力 ${ }_{w} Q_{h p}$, 他は梁端部の降伏耐力 $Q_{v}$ である. S3 は実験計画時の想定よりフラ ンジの降伏応力度が低くなったため梁端部降伏耐力が最小值となっ

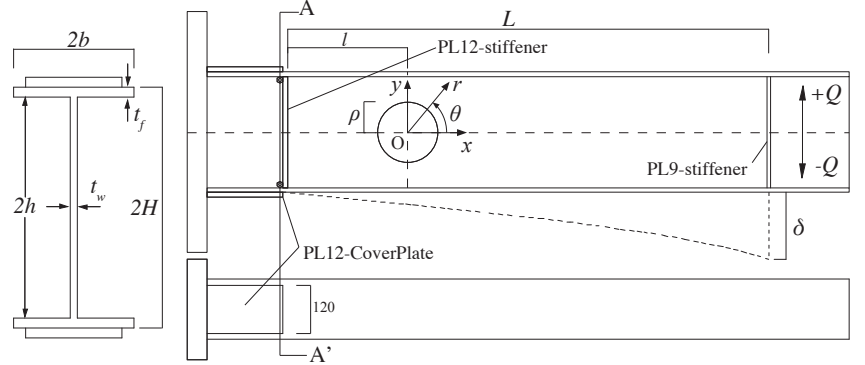

図 1 試験体概要

表 1 鋼材の機械的性質

\begin{tabular}{c|c|c|c|c|c|c|c}
\hline \multirow{2}{*}{ 鋼種 } & $\begin{array}{c}t \\
(\mathrm{~mm})\end{array}$ & $\begin{array}{c}\sigma_{y} \\
\left(\mathrm{~N} / \mathrm{mm}^{2}\right)\end{array}$ & $\begin{array}{c}\sigma_{u} \\
\left(\mathrm{~N} / \mathrm{mm}^{2}\right)\end{array}$ & $\begin{array}{c}E \\
\left(\mathrm{kN} / \mathrm{mm}^{2}\right)\end{array}$ & $\begin{array}{c}\text { Elng. } \\
(\%)\end{array}$ & $\begin{array}{c}\varepsilon_{y} \\
(\mu)\end{array}$ & $Y . R$. \\
\hline \hline \multirow{3}{*}{ H-SA700 } & 6 & 767 & 850 & 195 & 10.1 & 3936 & 0.90 \\
\cline { 2 - 8 } & 9 & 751 & 813 & 202 & 11.2 & 3720 & 0.92 \\
\cline { 2 - 8 } & 12 & 784 & 840 & 209 & 12.5 & 3759 & 0.93 \\
\hline \multirow{3}{*}{ SN400 } & 6 & 275 & 414 & 204 & 32.4 & 1349 & 0.67 \\
\cline { 2 - 8 } & 9 & 291 & 423 & 211 & 30.9 & 1384 & 0.69 \\
\cline { 2 - 8 } & 12 & 257 & 405 & 213 & 29.6 & 1205 & 0.63 \\
\hline
\end{tabular}

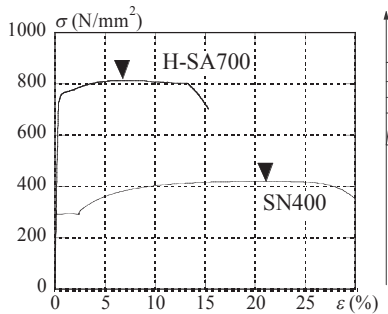

図 2 引張試験結果

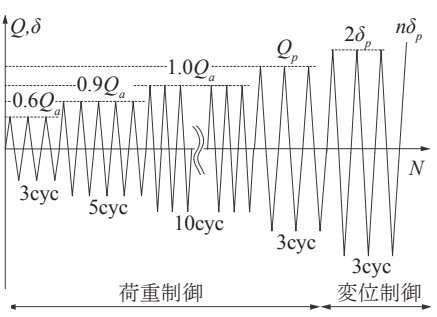

図 3 載荷プログラム

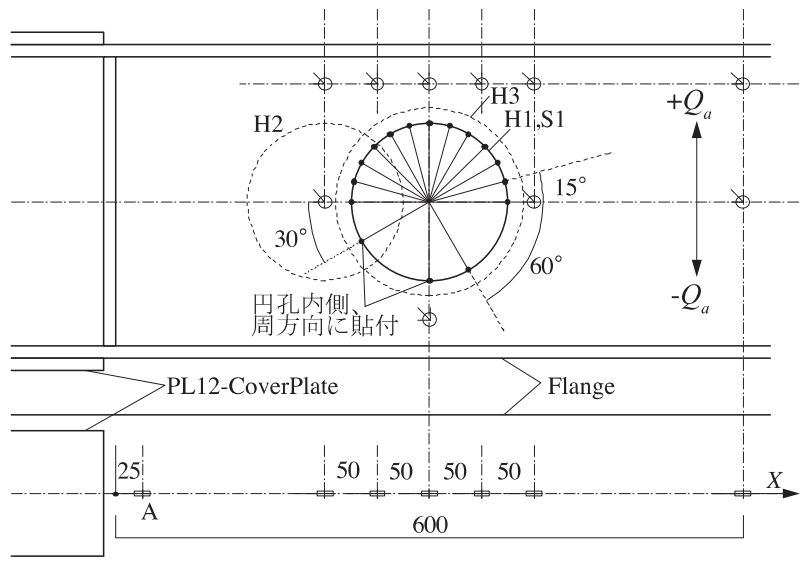

図 4 ひずみゲージ貼付位置

表 $2 Q$ の添字記号説明と各種耐力計算值

$\langle Q$ の添字 $\rangle \quad p$ : 全塑性耐力(せん断降伏) $y$ : 降伏耐力 $w$ : ウェブ断面による計算值 $h$ : 孔中心断面の計算值 $f:$ フィーレンデール効果考慮 $e: M-Q$ 関係考慮の全塑性耐力 $a:$ 基準耐力

\begin{tabular}{|c|c|c|c|c|c|c|c|c|c|c|c|c|c|c|c|c|c|c|c|}
\hline \multirow{3}{*}{ Name } & \multirow{2}{*}{\multicolumn{7}{|c|}{$\frac{\text { 試験体形状 }}{(\mathrm{mm})}$}} & \multirow{3}{*}{$\begin{array}{c}\frac{\text { 限芥歫離 }}{(\mathrm{mm})} \\
L_{s}\end{array}$} & \multirow{2}{*}{\multicolumn{4}{|c|}{$\frac{\text { 梁端部耐力 }}{(\mathrm{kN})}$}} & \multirow{2}{*}{\multicolumn{3}{|c|}{$\frac{\text { 孔部耐力 }}{(\mathrm{kN})}$}} & \multirow{2}{*}{\multicolumn{3}{|c|}{\begin{tabular}{|c|} 
フィーレンデール耐力 \\
$(\mathrm{kN})$
\end{tabular}}} & \multirow{3}{*}{$\frac{\text { 基準耐力 }}{Q_{a}}$} \\
\hline & & & & & & & & & & & & & & & & & & & \\
\hline & $L$ & $2 H$ & $2 b$ & $t_{f}$ & $t_{w}$ & $2 \rho$ & $l$ & & $Q_{p}$ & ${ }_{w} Q_{p}$ & $Q_{e}$ & $Q_{y}$ & $Q_{h p}$ & ${ }_{w} Q_{h p}$ & $Q_{h y}$ & $Q_{h f p}$ & ${ }_{w} Q_{h f p}$ & $Q_{f e}$ & \\
\hline H1(基本) & & & & & & $\overline{150}$ & $\overline{300}$ & 256 & 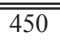 & 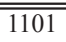 & $\overline{409}$ & 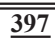 & "558 & $\overline{508}$ & "515 & 2558 & 4442 & $\overline{424}$ & $\overline{Q_{y}}$ \\
\hline H2(端部) & & & & & 9 & 150 & 200 & 257 & 449 & 1096 & 409 & 397 & 501 & 505 & 463 & 501 & 438 & 390 & $Q_{y}$ \\
\hline H3(孔大) & & & & & & 180 & 300 & 362 & 444 & 1088 & 404 & 392 & 532 & $\underline{383}$ & 498 & 532 & 314 & 384 & ${ }_{w} Q_{h p}$ \\
\hline H4(Web薄) & & & & & 6 & 150 & 300 & 233 & 413 & 762 & 375 & 371 & 521 & $\underline{350}$ & 485 & 521 & 304 & 397 & ${ }_{w} Q_{h p}$ \\
\hline H5(無孔) & 1200 & 300 & 150 & 12 & & - & - & - & 444 & 1090 & 404 & $\underline{392}$ & - & - & - & - & - & - & $Q_{y}$ \\
\hline S1(基本) & & & & & 9 & 150 & 300 & 257 & 155 & 428 & 141 & $\underline{131}$ & 190 & 198 & 170 & 190 & 172 & 146 & $Q_{y}$ \\
\hline S2(端部) & & & & & & 150 & 200 & 258 & 154 & 427 & 140 & $\underline{130}$ & 170 & 197 & 152 & 170 & 171 & 133 & $Q_{y}$ \\
\hline S3(孔大) & & & & & & 180 & 300 & 363 & 154 & 428 & 140 & $\underline{130}$ & 181 & 151 & 165 & 181 & 124 & 133 & $Q_{y}$ \\
\hline S4(Web薄) & & & & & 6 & 150 & 300 & 229 & 137 & 261 & 125 & 122 & 173 & $\underline{120}$ & 159 & 173 & 104 & 132 & ${ }_{w} Q_{h p}$ \\
\hline
\end{tabular}


た. $\pm 0.6 Q_{a}$ の載荷プログラムは殆ど弾性範囲における繰返しであり, $\pm 0.9 Q_{a}$ の載荷プログラムは H-SA700 の降伏応力度の算出が $0.2 \%$ オ フセット法を用いていることで非線形性を許容していることに加え, 著者らの有円孔平板に対する単軸引張圧縮実験 $\left.{ }^{8}\right)$ から最小断面の $0.9 \sigma_{y}$ 相当の荷重まで線形挙動を保ったということに関連する. 荷重 制御は $Q_{p}$ まで行い, それ以降は $\delta_{p}$ を用いた各変位における変位制 御で 3 周ずつの漸増載荷を行い, 十分に耐力が劣化するまで繰返す こととした

図 4 にひずみゲージ貼付位置を示す，黒点は孔縁の接線方向に貼 付した単軸 $2 \mathrm{~mm}$ ひずみゲージである. ウェブの孔周りには三軸ひ ずみゲージ，フランジには材軸方向に単軸 $5 \mathrm{~mm}$ ひずみゲージを貼 付している，孔周りのひずみゲージは各試験体の孔位置に合わせて 貼付している。

\section{2 荷重制御範囲の弾性挙動と変位増加}

図 5 に荷重制御範囲での各試験体の荷重変位関係を無次元化した 值で示す. SN400 を用いた試験体は代表して S1 のみ示す. 横軸の $\delta_{a}$ は孔欠損の無い全断面から算出した剛性から求まる值である. H5 以外の試験体は孔周辺のせん断変形の影響で剛性が低くなることが 分かる.また殆どの試験体が概衩線形挙動と捉えることが出来るが, (b)H2，(c)H3，(d)H4 はループをわずかに描いているように見える.

図 6 は変位の増減を分かりやすく寸る為に, 縦軸に各繰返しでの 正負両方合わせた変位 $(|+\delta|+|-\delta|)$ を 1 周目の変位 $\left(\left|+\delta_{1}\right|+\left|-\delta_{1}\right|\right)$ で 無次元化した值, 横軸に周数 $N$ をとったものである. 白抜きのプロ ットが H-SA700 の試験体で, 黒塗りが SN400 の試験体である．無 孔梁の $\mathrm{H} 5$ は実線で示している. $\mathrm{H} 5$ は $\pm 0.6 Q_{a}$ と $\pm 0.9 Q_{a}$ の繰返しで は変位は増加せず, むしろ繰返すごとに減少しているが, $\pm 1.0 Q_{a}$ の繰返しでは繰返すごとに増加している. $\pm 1.0 Q_{a}$ の荷重は梁端部フ ランジの縁が降伏する值であり, その影響と考えられる. そして孔 のある H-SA700 試験体, 特に加藤らの限界距離 ${ }^{9}$ を満たさない H2, H3, H4 は H5 よりも大きな割合で変位増加していることが分かる. これは孔の応力集中により孔周りでも降伏し, 変位増加の割合が増 幅した影響と考えられる。これは著者らの以前の一軸引張圧縮載荷 実験 ${ }^{8)}$ と同様の傾向であり, 高強度鋼の降伏による繰返し特性がウ ェブ有孔梁でも表れることが確認できる，一方，SN400 試験体につ いては全試験体で殆ど 1 周目の変位を超えることは無いことが分か る.これらは降伏した部分がひずみ硬化することで, 応力を負担し, 全体の変形が抑制されるためである.

図 7 に梁端部のひずみ度の様子を示す. 左側(a)の図は無孔試験体 H5 について, 横軸にフランジ梁端部である図 4 中の A の位置に貼 付したひずみゲージの值, 縦軸に荷重をそれぞれ無次元化した值を とっている. 図 5(e)の全体挙動よりはっきりとループを描いている. 右側(b)の図は H-SA700 試験体全てについて正側 $+Q_{a}$ における, フラ ンジ梁端部のひずみ度の増減を降伏ひずみ度で無次元化した值を縦 軸に, 周数 $N$ を横軸に示している. 全試験体が $+0.9 Q_{a}$ もしくは $+1.0 Q_{a}$ で繰返すごとにわずかにひずみ度が増加する傾向を示している．こ こで $\mathrm{H} 3$ や $\mathrm{H} 4$ の $+1.0 Q_{a}$ の值は孔中心断面位置でせん断降伏する時の 值 ${ }_{w} Q_{h p}$ であるが，降伏ひずみ度に達している．また $\mathrm{H} 2$ は孔位置が 梁端部に近いため, 無次元化したひずみ度が 1.0 を明らかに超えて いる．これは孔の応力集中が梁端部にまで影響することで，ひずみ 度が大きくなっていることが考えられる. しかし各試験体の繰返し

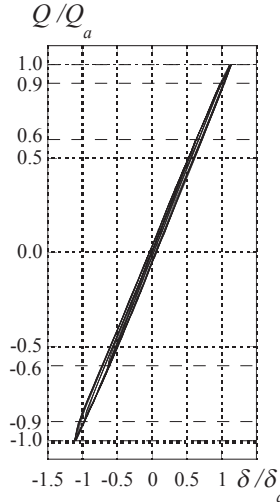

(a) $\mathrm{H} 1$

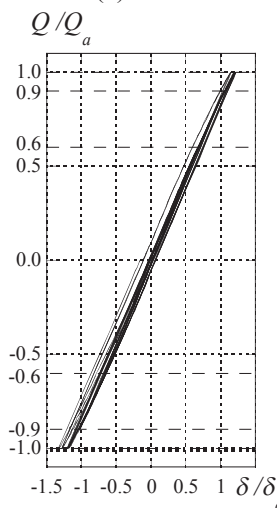

(d) $\mathrm{H} 4$

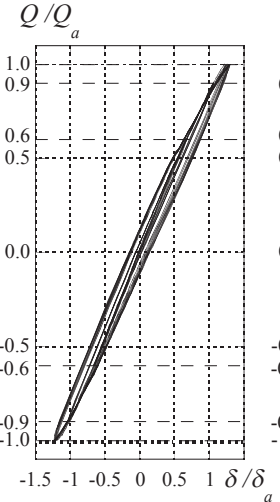

(b) $\mathrm{H} 2$

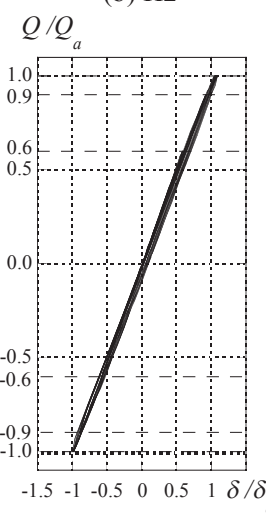

(e) $\mathrm{H} 5$

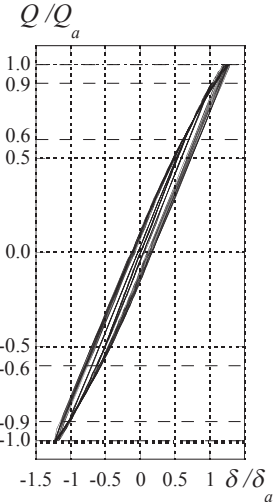

(c) $\mathrm{H} 3$

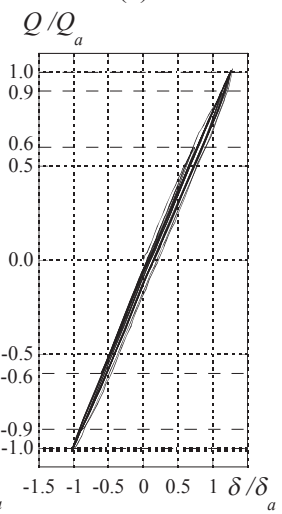

(f) $\mathrm{S} 1$
図 5 荷重変位関係（荷重制御範囲）

$|+\delta|+|-\delta| /\left|+\delta_{1}\right|+\left|-\delta_{l}\right|$

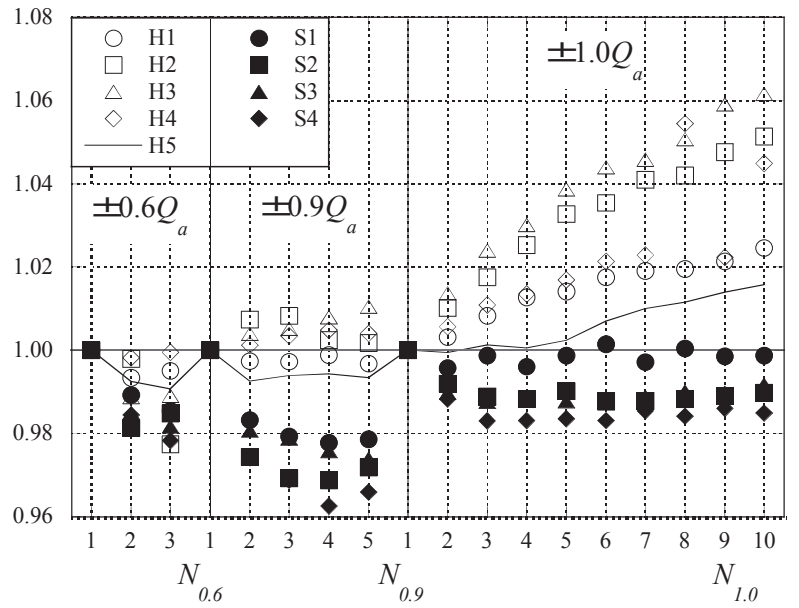

図 6 変位増加の様子

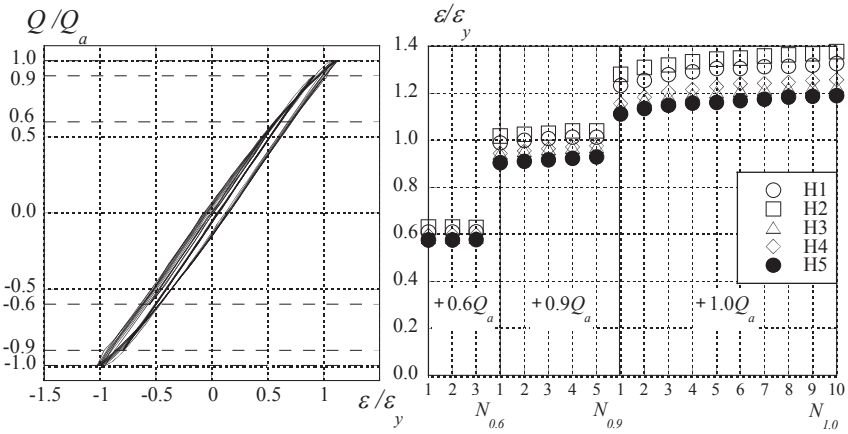

(a) H5 荷重ひずみ度関係

(b) 梁端部ひずみ度の進展

図 7 梁端部のひずみ度の様子 


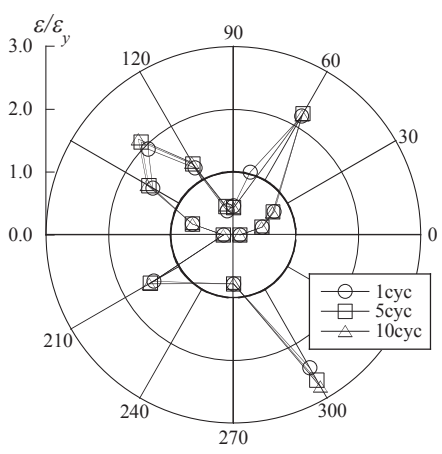

(a) $\mathrm{H} 1 /+Q_{a} /$ hole

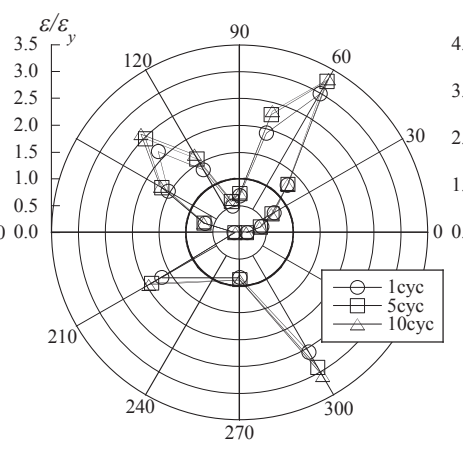

(b) $\mathrm{H} 2 /+Q_{a} /$ hole

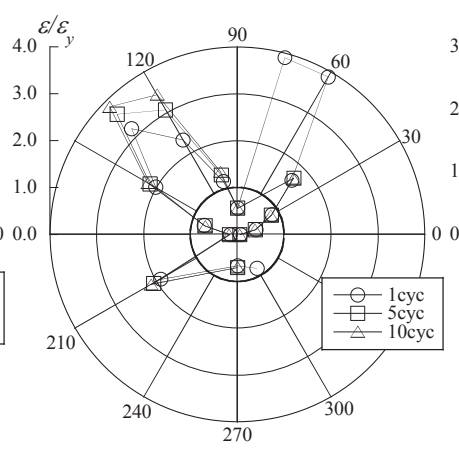

(c) $\mathrm{H} 3 /+Q_{a} /$ hole

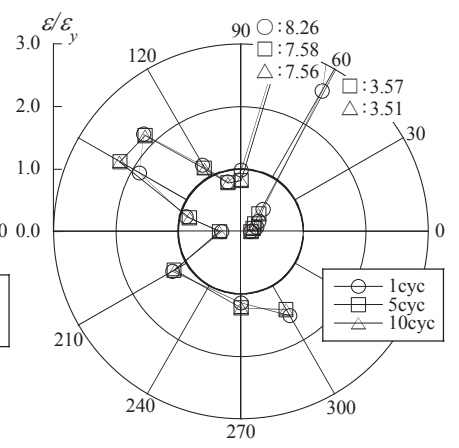

(d) $\mathrm{S} 1 /+Q_{a} /$ hole

図 8 孔縁のひずみ度分布

による増加の割合には大きな差異がなく, 同程度である. すなわち 図 6 で示した全体挙動の変位増加の割合が大きくなるのは, 孔周り の局所的塑性化の度合によるものであると考えられる。

\section{3 孔周りの局所的塑性化の進展}

図 8 に $+1.0 Q_{a}$ の繰返し時の孔縁のひずみ度分布として (a) $\mathrm{H} 1,(\mathrm{~b}) \mathrm{H} 2$, (c)H3, (d)S1 のものを示寸. 図 1 に示した孔中心を原点とした極座 標形式であり, 動径の長さは無次元化したひずみ度を絶対值化した 值で示している. 図40黒点で示したひずみゲージの值で, 繰返し $1 ， 5,10$ 周目を $\bigcirc, \square, \triangle$ の順にプロットで示している. 動径の長 さの目盛に注意すると, H-SA700 試験体の中でも(a)H1 に比べて, (b)H2, (c)H3 の局所的塑性化が大きく進行している. また $60^{\circ}$, $135^{\circ}$ 付近の降伏した部分では繰返すごとにひずみ度が大きくなっ ていることが確認できる. 特に(b)H2, (c)H3 では繰返すごとに, 最 も降伏が進んだ部分の周囲でも大きくなっている，これは高強度鋼 H-SA700の応力度ひずみ度関係がなだらかに塑性化することや降伏 比が非常に高いことが理由として考えられる. (d)S1 は降伏した部分 の $60^{\circ}$ や $75^{\circ}$ のひずみ度の值が急激に大きくなる. 普通鋼 SN400 は図中に数字で示すように降伏した部分は硬化するため, 繰返しで ひずみ度は変わらないもしくは下がる傾向にある.

図 9 に $+Q_{a}$ 時の繰返しにおけるフランジの材軸方向のひずみ度分 布を示す. 1 周目, 10 周目をそれぞれ白, 黒で示し, 各試験体の孔 位置を図示してある。ひずみ度分布は無孔の H5 がほぼ線形である のに対し, 有孔試験体は孔周辺で乱れている. H2, H3 は孔上のひ ずみ度が梁端部のひずみ度より高く, 孔周辺で大きな変形をしてい ることが分かる.さらに繰返しによるひずみ度の増加も顕著である. $\mathrm{H} 4$ は H1 とほぼ同じ分布であり, 孔周辺での分布の乱れは小さく, 繰返しによるひずみ度の増加も殆どない.

図 10 に H-SA700 試験体の三軸ひずみゲージから算出する孔周り の主応力図を示す. $+0.9 Q_{a}$ の 5 周目を $(\mathrm{a}) \sim(\mathrm{d})$ に, $+1.0 Q_{a}$ の 10 周目を (e) (h)に示している. 矢印で示された長さ, 向きが主応力度の大き さ, 方向である. $x y$ 直交座標系において下式(1)で示される $\sigma_{m}$ をミ 一ゼス応力度と定義し, 降伏応力度 $\sigma_{y}$ による降伏の判断を行う.

$$
\sigma_{m}=\sqrt{\sigma_{x}^{2}+\sigma_{y}^{2}-\sigma_{x} \sigma_{y}+3 \tau_{x y}^{2}}
$$

ここで, $\sigma_{m}$ : ミーゼス応力度, $\sigma_{x}: x$ 軸方向の直応力度, $\sigma_{y}: y$ 軸方 向の直応力度, $\tau_{x y}$ : 座標 $(x, y)$ 地点におけるせん断応力度である.

降伏した場合はその三軸ひずみゲージの位置を黒丸にし, 主応力 度の大きさを点線で示している. なお各位置を(a)に示した番号でこ

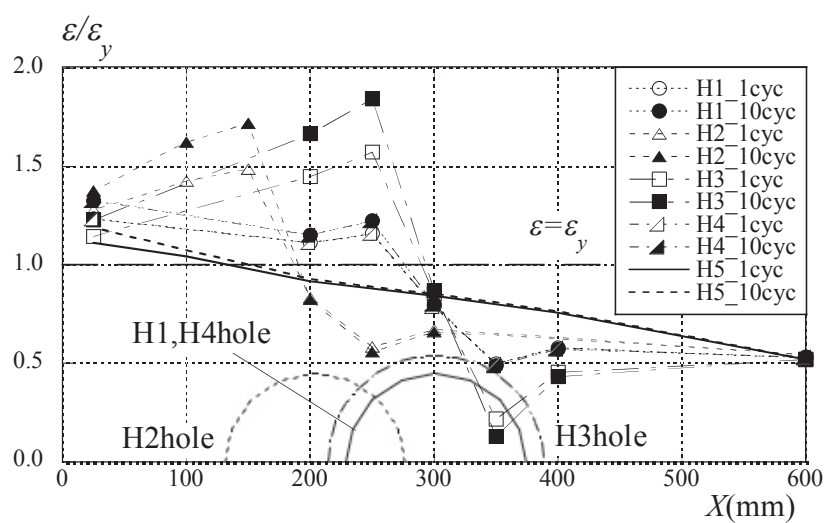

図 9 フランジひずみ度の様子

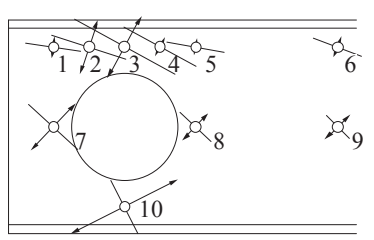

(a) $\mathrm{H} 1 /+0.9 Q_{a} / 5$ cyc

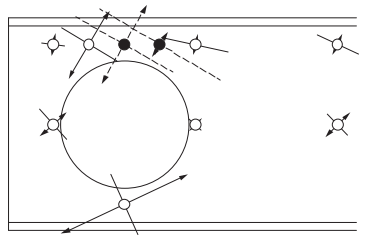

(c) $\mathrm{H} 3 /+0.9 Q_{a} / 5$ cyc

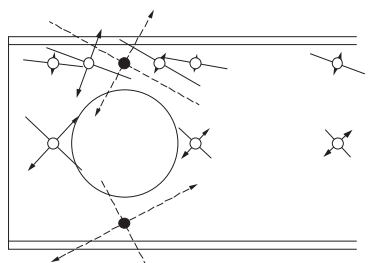

(e) $\mathrm{H} 1 /+Q_{a} / 10$ cyc

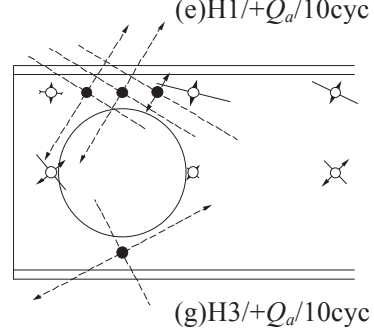

(g) $\mathrm{H} 3 /+Q_{d} / 10 \mathrm{cyc}$

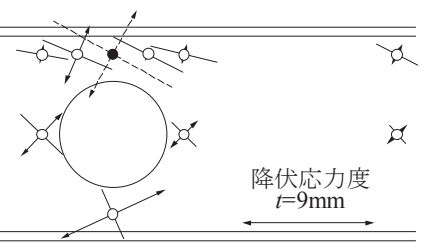

(b) $\mathrm{H} 2 /+0.9 Q_{a} / 5$ cyc
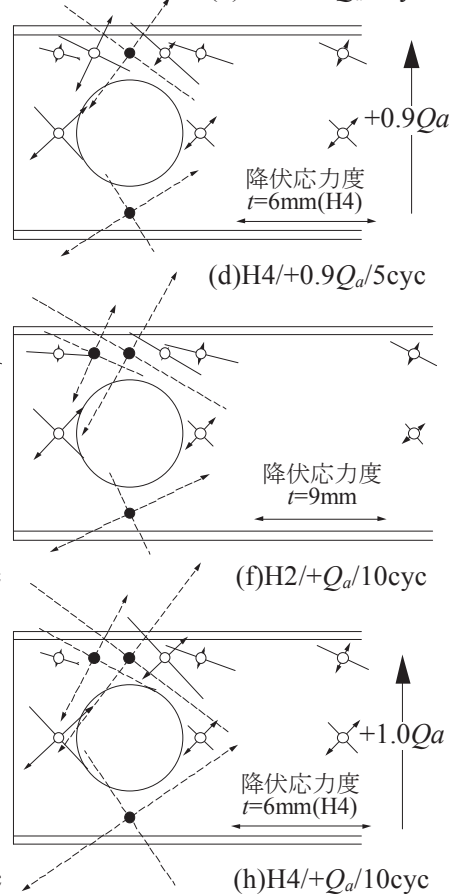

図 10 主応力図 
れより記述する. まず全試験体で No.7 9 の部分は殆ど純せん断状 態であり, 孔の左右にある No.7 と No.8 では梁端部側の No.7 の矢印 の長さが長くなっている. また $\mathrm{H} 3$ は三軸ひずみゲージの位置が他 の試験体より孔縁に近い位置であるために小さくなっていると考え られる。全試験体で孔位置から十分に遠く, 曲げの影響を受ける No.6 は材軸方向で同一直線上に貼付された No. や No. 5 と大差ない. つまり No.2 4 の部分で応力集中の影響が出ていると判断できる. 特に最小断面上の No. 3 やNo.10 では応力集中し, $\mathrm{H} 1$ 以外は(b) $+0.9 Q a$ の 5 周目には降伏している. H3 は No.4でも降伏し, 塑性化が広範 囲に広がっている。その後 $+1.0 Q_{a}$ の繰返し時には全試験体で No.3 と No.10 が降伏し, H1 以外は No.2 や No.4 の位置でも降伏する. 寸 なわち No.3の降伏後は周囲に塑性化が広がることが分かる.

図 11 は $\mathrm{H} 1$ と $\mathrm{H} 3$ の No.2, 3, 4 のミーゼス応力度 $\sigma_{m}$ の正側 $+Q_{a}$ の繰返しにおける進展の様子を示している. 図7(b)と比べて, 降伏 した部分の值は繰返すごとに明らかに大きくなっている. また降伏 前であってもわずかに増加傾向を示すのは，0.2\%オフセット法の降 伏応力度の算出が非線形性を許容していることの影響と考えられる.

\section{3. 高強度鋼を用いた有孔梁の許容降伏耐力}

本章ではこれまでの結果をもとに, 弾性設計を基本とした場合の 高強度鋼の許容降伏耐力について考える. まず無孔梁 H5 の場合は, 図 6 より $\pm 0.9 Q_{y}$ では線形挙動であり， $\pm 1.0 Q_{y}$ でわずかであるが変 位増加の挙動を示している。このことから梁端部の応力度が非線形 域に到達しない降伏耐力の 0.9 倍以下と寸ることが妥当である。限 界距離を満たす $\mathrm{H} 1$ は図 5 , 図 6 より孔周りの局所的塑性化による変 位増加は小さいので許容降伏耐力は $\mathrm{H} 5$ と同じく $\pm 0.9 Q_{y}$ で良いと考 えられる。また限界距離を満たさない場合については孔周辺の応力 集中による局所的塑性化の影響を無視できないと考える。そこで本 章は弾性理論から孔周辺部の応力集中を考慮した降伏耐力 $Q_{c}$ と変 位増加が大きくなる耐力 $Q_{F}$ を提案する.

\section{1 孔縁の応力度分布}

ここでは孔による応力集中で孔縁の一部が降伏する耐力 $Q_{c}$ を算 出する. 曲げせん断力を負担する $\mathrm{H}$ 形鋼の孔周辺部で最も応力集中 するのは孔縁なので ${ }^{11)}, Q_{c}$ は孔周辺部の弾性限耐力といえる.

まず孔のあるウェブが負担する力の仮定を図 12 に示す。一般に H 形断面のウェブが負担する力は曲げせん断力である。この曲げせん 断力が作用寸る状態を(a)のようにウェブせい $2 h$ を用いて, 高さ $2 h$ の帯板に純せん断力が作用寸る場合と等曲げが作用する場合の重补 合わせでモデル化する．このモデル化によりフランジの影響を無視 した孔のある帯板の応力集中の問題となり, 過去の多くの知見を利

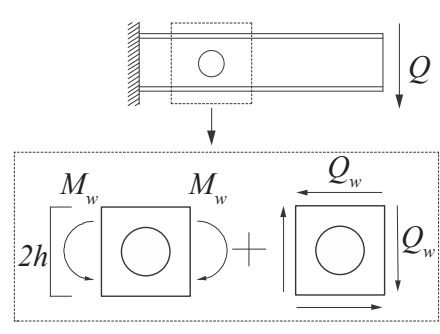

(a) 曲げせん断状態の変換

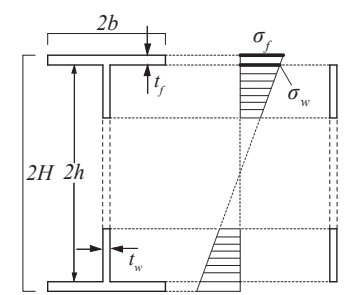

孔中心断面 $\sigma_{x}$ 分布 ウェブ断面 (b) $M_{w}$ の導出
図 12 孔周辺にかかる力の仮定

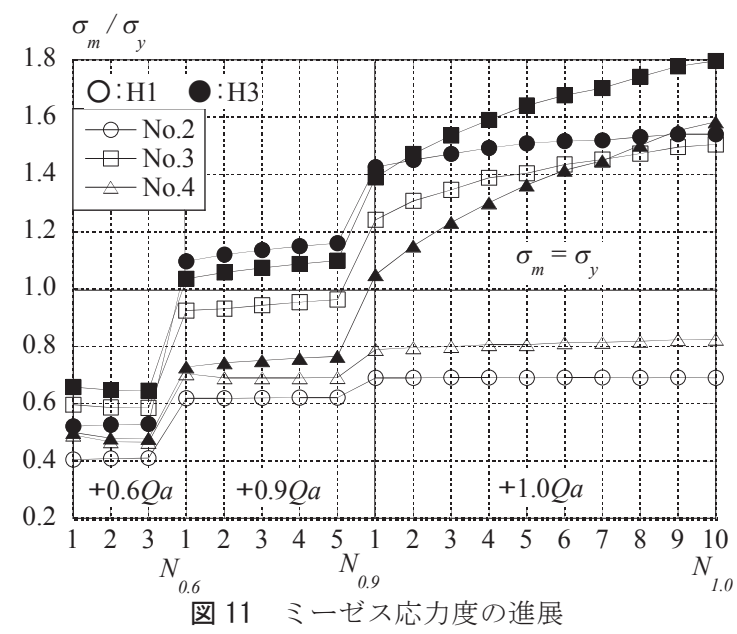

用できる. あわせて孔径と帯板幅の比 $(\rho / h)$ や孔位置の変化 $(l)$ に簡 便に対応できる.

帯板に作用する純せん断力はフランジのせん断力負担を考虜した 荷重 $Q_{w}{ }^{12}$ を用いる. せん断応力度 $\tau_{w}$ は幅 $2 h$ の断面欠損の無い帯板 で算出する. $Q_{w}, \tau_{w}$ を下式(2), (3)に示す.

$$
\begin{aligned}
Q_{w} & =\frac{Q}{I}\left\{2 b t_{f}\left(2 H-t_{f}\right) h+\frac{t_{w}(2 h)^{3}}{12}\right\} \\
\tau_{w} & =Q_{w} /\left(t_{w} \times 2 h\right)
\end{aligned}
$$

ここで， $Q_{w}$ : ウェブに作用するせん断力， $\tau_{w}$ : 断面欠損無しのウェ ブのせん断応力度, $I$ : 断面欠損無しの $\mathrm{H}$ 形断面全体の断面 2 次モー メント, $t_{f}$ : フランジ厚, $t_{w}$ : ウェブ厚, $2 b$ : フランジ幅, $2 H$ : 梁せ い, $2 h:$ ウェブせいである.

等曲げのモーメント $M_{w}$ の值は孔の中心を通る断面に作用寸るモ 一メント $Q(L-l)$ に係数 $z$ を乗じた值とする. $M_{w}$ の導出と係数 $z$ を下 式に示す。

$$
\begin{aligned}
& M_{w}={ }_{w} Z_{h} \times \sigma_{w}={ }_{w} Z_{h} \times\left(\frac{h}{H}\right) \sigma_{f}={ }_{w} Z_{h} \times\left(\frac{h}{H}\right)\left(\frac{Q(L-l)}{Z_{h}}\right)=z \times Q(L-l) \\
& z=\left(h \times{ }_{w} Z_{h}\right) /\left(H \times Z_{h}\right)
\end{aligned}
$$

ここで, $M_{w}$ : 幅 $2 h$ の帯板が負担する曲げモーメント, ${ }_{w} Z_{h}:$ 孔中心 を通る断面のウェブだけの断面係数, $\sigma_{w}$ : ウェブ縁位置での $x$ 軸方 向の直応力度, $\sigma_{f}$ : フランジ縁位置での $x$ 軸方向の直応力度, $Z_{h}$ : 孔 中心を通る $\mathrm{H}$ 形断面全体の断面係数, $L$ : 材長, $l$ : 梁端部から孔中 心までの距離である.

$M_{w}$ はまず図 12(b)に示すように孔中心断面での応力集中を考えな い応力分布から縁応力度 $\sigma_{f}$ を求める. これを用いてウェブの縁位置 での応力度 $\sigma_{w}$ を求め, ウェブ断面の帯板にモーメントを作用させた とき, 縁応力度が $\sigma_{w}$ になるモーメントとして $M_{w}$ を算出している.

$$
\begin{aligned}
{ }_{\tau} \sigma_{\theta} & =\tau_{w}\left(1+\frac{3 \rho^{4}}{r^{4}}\right) \sin 2 \theta \\
{ }_{M} \sigma_{\theta} & =\frac{3 M_{w} \rho^{3}}{2 t_{w} h^{3}}\left\{\left(\frac{\rho}{r^{3}}-\frac{3 \rho^{3}}{r^{5}}\right) \sin \theta+\left(\frac{r}{\rho^{3}}-\frac{\rho}{r^{3}}+\frac{4 \rho^{3}}{r^{5}}\right) \sin ^{3} \theta\right\}
\end{aligned}
$$

ここで, ${ }_{\tau} \sigma_{\theta},{ }_{M} \sigma_{\theta}$ : 純せん断力, 等曲げによる孔縁での孔接線方向 の直応力度, $\rho$ : 孔半径, $r$ : 極座標における動径の長さである.

上式(6), (7)は帯板幅が無限大のときの孔中心を原点とする極座標 系(図 1)で表した接線方向の応力度の式 $\left.{ }^{11)}, 13\right)$ である. ${ }_{\tau} \sigma_{\theta}$ は純せん 断力, ${ }_{M} \sigma_{\theta}$ は等曲げによる応力度である. 孔縁には接線方向にのみ 応力が存在するのでこの式に $r=\rho$ を代入した值で降伏を判断する. 
帯板幅を有限とした場合は過去に様々な研究 ${ }^{14) 17)}$ が行われてい るが, 応力関数を級数で仮定し, 複素関数解析する手法がとられ, 式は非常に煩雑である.その式は本研究が必要とする精度を逸脱し ているため, 本研究では無限幅の上式を板幅と孔直径の比率を考慮 した応力集中係数による係数 $\alpha, \beta$ を用いて係数倍し, 近似すること とした. 応力集中係数は複素応力関数の双極座標系を用いて半無限 幅の板の場合の応力関数を定めて, 有限幅に還元した鵜戸口の值 ${ }^{18)}$ を用いる.これは Howland ${ }^{19),}{ }^{20)}$ の值ともよく一致し, 加えて半無限 板の想定から孔直径が大きい場合でも精度の高い解が出せることが 特徵である。

図 13 に鵜戸口の応力集中係数 ${ }^{18)}$ を示す。横軸は板幅と孔直径の 比率 $\rho / h$ である. (a)純せん断状態の場合の縦軸に示した係数 $\kappa_{\tau}$ は最 小断面の平均せん断応力度に対する比率であり， $\rho / h$ が 0 の場合に 係数が 4 となり, 無限幅の式(6)に一致して, 孔が大きくなると無限 大に発散する. (b) 等曲げの場合の係数 $\kappa_{M}$ は最小断面の断面係数か ら求まる孔縁の応力に対する比率である。板幅に関係なくほぼ 2.0 である. $\kappa_{\tau}, \kappa_{M}$ から求まる最大応力度の值を下式に示す。

$$
{ }_{\tau} \sigma_{\kappa}=\kappa_{\tau} \frac{Q_{w}}{2 t_{w}(h-\rho)} \quad \text { (8a) } \quad, \quad{ }_{M} \sigma_{\kappa}=\kappa_{M} \frac{3 M_{w} \rho}{2 t_{w}\left(h^{3}-\rho^{3}\right)}
$$

ここで, ${ }_{\tau} \sigma_{\kappa},{ }_{M} \sigma_{\kappa}$ : 鵜戸口の応力集中係数から求まる純せん断力, 等曲げによる孔縁での最大応力度, $\kappa_{\tau}, \kappa_{M}$ : 鵜戸口の求めた純せん 断状態，等曲げ状態での応力集中係数である.

次に式(6), (7)から求まる最大応力度の值を示寸. 純せん断状態の 場合は $\sin 2 \theta=1$, 等曲げの場合は $\sin \theta=1$ で最大值をとる.

$$
{ }_{\tau} \sigma_{\max }=4 \tau_{w}=\frac{2 Q_{w}}{t_{w} h} \quad(9 \mathrm{a}) \quad, \quad{ }_{M} \sigma_{\max }=\frac{3 M_{w} \rho}{t_{w} h^{3}}
$$

ここで, ${ }_{\tau} \sigma_{\max },{ }_{M} \sigma_{\max }$ : 無限遠の式(6), (7)から求まる孔縁での最大 応力度である。

式(8)と式(9)が等しくなるように係数 $\alpha_{\tau}, \beta_{M}$ を定めると, 下式のよ うになる。

$$
\alpha_{\tau}=\frac{\kappa_{\tau} h}{4(h-\rho)} \quad(10 \mathrm{a}) \quad, \quad \beta_{M}=\frac{\kappa_{M} h^{3}}{2\left(h^{3}-\rho^{3}\right)}
$$

以上より求めたい孔縁の応力分布は重数合わせて, 下式で表せる. 孔縁なので, ${ }_{\tau} \sigma_{\theta},{ }_{{ }_{N}} \sigma_{\theta}$ には $r=\rho$ を代入する.

$$
\sigma_{\theta}=\alpha_{\tau \tau} \sigma_{\theta}+\beta_{M M} \sigma_{\theta}
$$

ここで， $\sigma_{\theta}$ : 純せん断状態，等曲げ状態を重ね合わせた孔縁での接 線方向の直応力度である.

これで最も応力集中する孔縁の応力度が分かり, その最大值から 弾性限耐力 $Q_{c}$ が算出できる. 図 14 に限界距離を満たしていない試 験体 H2 で+0.6Qa の場合で式(11)の検証結果を示寸. 図 8 と同様に 動径の長さが無次元化したひずみ度を絶対值化した值を示している. 実験值をプロットで示し, 実線が式(11)の值で，点線は有限要素法 汎用プログラムABAQUS を用いて弾性解析を行った結果である。 この有限要素法による数值解析では H 形鋼をフランジ， ウェブとも に 4 節点シェル要素を用いて構成し, メッシュは十分に細かくして いる. 理論值, 数值解析值はわずかな差異はあるものの, 殆ど実験 值とあっている. また最もひずみ度が大きくなる位置は $\cos \theta=1 / 2$ 周 辺であり，他の試験体でも同様である，よって最大応力度の位置を $\cos \theta=1 / 2$ と寸れば, 式(11)は下式(12)のようになり, 弾性限耐力 $Q_{c}$

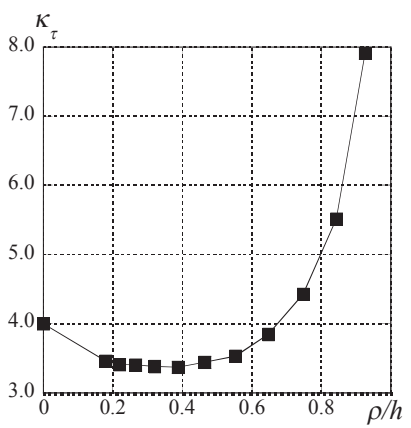

(a) 純せん断状態

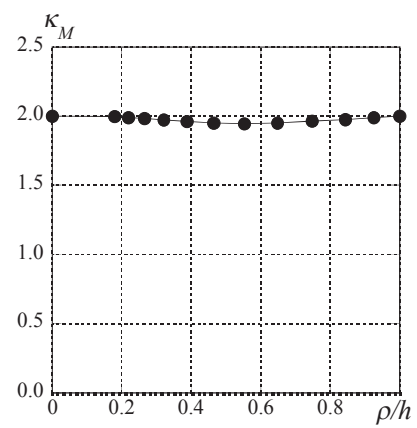

(b) 等曲げ状態
図 13 応力集中係数

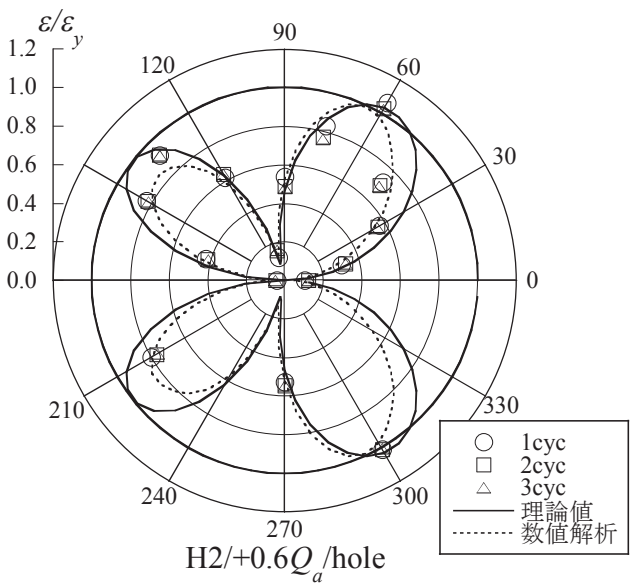

図 14 孔縁のひずみ度分布による検証 (H2)

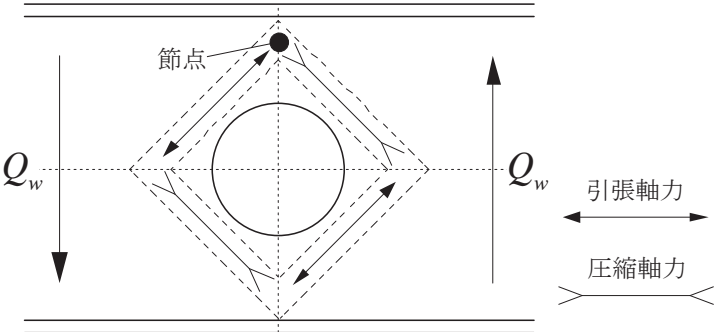

図 15 せん断力伝達機構

は下式(13)より求まる

$$
\begin{aligned}
& \sigma_{\cos \theta=1 / 2}=\frac{\sqrt{3}}{4 t_{w}}\left(\frac{\kappa_{\tau} Q_{w}}{h-\rho}+\frac{3 z \kappa_{M} \rho Q(L-l)}{2\left(h^{3}-\rho^{3}\right)}\right) \\
& Q_{c}=\frac{\sigma_{y}}{\sigma_{\cos \theta=1 / 2}} Q
\end{aligned}
$$

ここで， $\sigma_{\cos \theta=1 / 2}:$ 孔縁の応力度分布 $\sigma_{\theta}$ の $\cos \theta=1 / 2$ 位置での応力度, $\sigma_{y}$ : 降伏応力度, $Q_{c}$ : 弾性限耐力である.

\section{2 許容降伏耐力}

前節では応力集中を考慮した全範囲が弾性である弾性限耐力 $Q_{c}$ を求めた。これを許容降伏耐力とすれば安全ではあるが, 図 6 , 図 8 より降伏範囲は局所的であり，全体挙動への影響は小さい。そこで 孔中心を通るウェブ最小断面の応力度分布から求める許容降伏耐力 $Q_{F}$ を提案する. 最小断面上には孔縁に次いで大きく応力集中する部 分があり, 図 10, 図 11 より最小断面上の No.3 が降伏すると周辺も すぐに降伏し，局所的塑性化が拡がる。この時，繰返しによるひず み度の増加も顕著である。加えて最小断面上の No.3 の降伏は図 6 で全体挙動が変位増加を示すときにも一致している，孔のある場合 
のせん断力伝達機構は図 15 のように形成されることが知られてお $り^{21)}$, その節点位置での降伏は孔周辺部での変形を大きくするため, 全体挙動の変位増加を増幅すると考えられる.

最小断面の応力分布を前節と同様に鵜戸口の応力集中係数 ${ }^{18)}$ と無 限幅の応力状態式 ${ }^{11)}$, 13) から求める. 式の簡略化の為, 図 1 の $x y$ 直 交座標を用いて表現する。 まず無限幅の式を示す．純せん断力から は最小断面にせん断応力度のみ発生するので下式(14)のみで表せる.

$$
{ }_{\tau} \tau_{x y}=\tau_{w}\left(1+\frac{2 \rho^{2}}{y^{2}}-\frac{3 \rho^{4}}{y^{4}}\right)
$$

ここで, ${ }_{\tau} \tau_{x y}$ : 純せん断力から生じる孔中心を通る断面のせん断応 力度, $\tau_{w}$ : 断面欠損のない部分でのせん断応力度である.

等曲げからは垂直応力度のみとなり下式(15), (16)で表される.

$$
\begin{aligned}
& { }_{M} \sigma_{x}=\frac{3 M_{w}}{2 t_{w} h^{3}}\left(y+\frac{\rho^{6}}{y^{5}}\right) \\
& { }_{M} \sigma_{y}=\frac{3 M_{w} \rho^{4}}{2 t_{w} h^{3}}\left(\frac{1}{y^{3}}-\frac{\rho^{2}}{y^{5}}\right)
\end{aligned}
$$

ここで, ${ }_{M} \sigma_{x},{ }_{M} \sigma_{y}$ : 等曲げによる孔中心を通る断面の $x$ 軸, $y$ 軸 方向の直応力度である.

(14)，(15)，(16)の 3 式にそれぞれ鵜戸口の応力集中係数から求ま る式(10)の係数 $\alpha_{\tau}, \beta_{M}$ を乗ずれば応力状態が表現できる. 降伏を判断 すべく式(1)と同様にミーゼス応力度 $\sigma_{m}$ を求める.

$$
\sigma_{m}=\sqrt{\beta_{M}^{2}\left({ }_{M} \sigma_{x}^{2}+{ }_{M} \sigma_{y}^{2}-{ }_{M} \sigma_{x M} \sigma_{y}\right)+3 \alpha_{\tau}{ }_{\tau} \sigma_{x y}^{2}}
$$

ここで, $\sigma_{m}$ : 純せん断状態, 等曲げ状態を重祮合わせた孔中心を通 る断面でのミーゼス応力度である。

図 16 に $+0.6 Q a$ のときの最小断面の応力度分布を限界距離を満た していない(a)H3, (b)H4 について示す. 縦軸には原点からの距離 $y$ を孔径 $\rho$ で無次元化した值, 横軸にはミーゼス応力度 $\sigma_{m}$ を降伏応力 度 $\sigma_{y}$ で無次元化した值を示している. 式(17)から求まる理論值を実 線で示し, $\triangle$ のプロットは数值解析の結果, வは実験值である. 理 論值は実験值, 数值解析值と孔に近い部分ではよく一致し, 孔から 離れると高い值を示している。これは無限幅全体に最も大きな孔縁 の応力集中係数を用いているためである. よって最小断面における 最大応力度を $y=h$ の位置で算出すれば十分に安全側になる. 式(17) に $y=h$ を代入した場合の最大応力度の式を下式(18)に示し, そこか ら求まる耐力を $Q_{F 1}$ として下式(19)に示す. 簡略化のため式(20), (21) のように記号 $\lambda ， y_{1}, y_{2}$ を新たに用いている.

$$
\begin{aligned}
& { }_{\max } \sigma_{m}=\sqrt{3\left(\alpha_{\tau} \frac{Q_{w}}{2 h t_{w}}\right)^{2} y_{1}+\left(\beta_{M} \frac{3 z Q(L-l)}{2 t_{w} h^{2}}\right)^{2} y_{2}} \\
& Q_{F 1}=\frac{\sigma_{y}}{\max _{m} \sigma_{m}} Q \\
& \left.\begin{array}{l}
y_{1}=\left(1+2 \lambda-3 \lambda^{2}\right)^{2} \\
y_{2}=1-\lambda^{2}+3 \lambda^{3}+\lambda^{4}-3 \lambda^{5}+2 \lambda^{6}
\end{array}\right\} \\
& \lambda=\left(\frac{\rho}{h}\right)^{2}
\end{aligned}
$$

ここで, $\max _{m}$ : 孔中心を通る最小断面のミーゼス応力度の最大值, $\lambda$ : 孔径と帯板幅の比の 2 乗, $y_{1}, y_{2}$ : 純せん断状態, 等曲げ状態の $\lambda$ の多項式, $\sigma_{y}$ : 降伏応力度, $Q_{F 1}$ : 応力集中を考慮した許容降伏耐 力である.

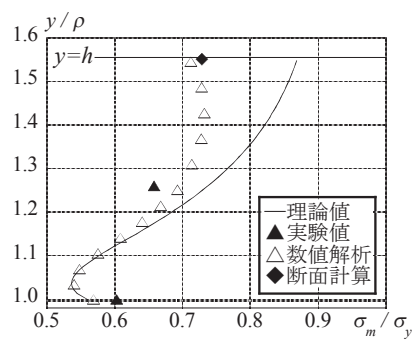

(a) $\mathrm{H} 3$ ミーゼス応力度

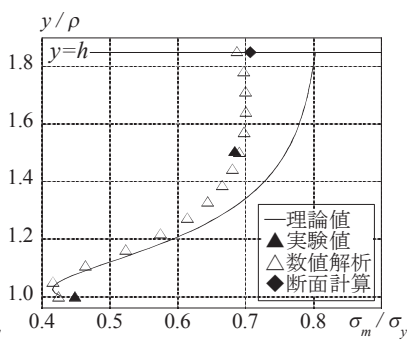

(b) $\mathrm{H} 4$ ミーゼス応力度
図 16 最小断面のミーゼス応力度

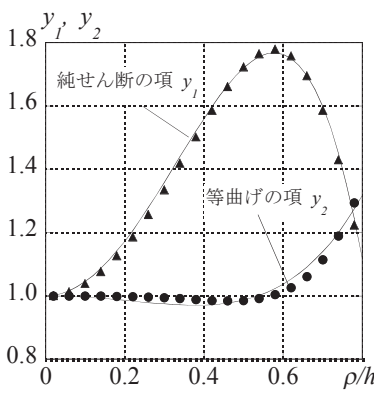

表 3 降伏耐力の計算結果

図 17 多項式の近似

\begin{tabular}{|c|c|c|c|}
\hline Name & $Q_{c o} / Q_{a}$ & $Q_{F} / Q_{a}$ & $Q_{F 2} / Q_{a}$ \\
\hline \hline $\mathrm{H} 2$ & 0.57 & $0.82(0.82)$ & 0.89 \\
\hline $\mathrm{H} 3$ & 0.42 & $0.67(0.67)$ & 0.79 \\
\hline $\mathrm{H} 4$ & 0.47 & $0.72(0.72)$ & 0.82 \\
\hline
\end{tabular}

現実的な孔径と板幅の比 $\rho / h$ を $0 \sim 0.8$ として, $y_{1}, y_{2}$ を 2 次式で近 似した様子を図 17 に示寸.プロットが元の值で近似した 2 次式の值 を実線で示している。この近似した 2 次式を下式(22)に示す.

$$
\left.\begin{array}{l}
y_{1}=1+4.6 \lambda-6.9 \lambda^{2} \\
y_{2}=1-0.4 \lambda+1.4 \lambda^{2}
\end{array}\right\}
$$

図 16 よりこの降伏耐力 $Q_{F 1}$ は少し安全側に取りすぎる場合がある。 そこで, 孔から離れた $y=h$ の位置では応力集中の影響は無くなると 考え, その位置のミーゼス応力度 $\sigma_{m h}$ を断面計算から算出する. 図 16 にマで示し，算出過程を下式(23)，(24)に示寸.

$$
\begin{aligned}
\sigma_{m h} & =\sqrt{3\left(\frac{Q_{w}}{2 t_{w}(h-\rho)}\right)^{2}+\left(\frac{M_{w}}{{ }_{w} Z_{h}}\right)^{2}} \\
Q_{F 2} & =\frac{\sigma_{y}}{\sigma_{m h}} Q
\end{aligned}
$$

ここで, $\sigma_{m h}: y=h$ の位置での断面計算によるミーゼス応力度, $\sigma_{y}$ : 降伏応力度, $Q_{F 2}$ : 断面計算による許容降伏耐力である.

この $\sigma_{m h}$ は図 16 より数值解析值とよく一致している. また式(23) より $\sigma_{m h}$ はウェブ板の負担する力 $M_{w}, Q_{w}$ を求め, 断面欠損を考慮 した断面係数，断面積だけで容易に算出できる. しかし孔径がウェ ブせいに対して大きくなると, 最小断面のミ一ゼス応力度分布の最 大值が $y=h$ とは限らない場合もあるので, 注意が必要である. 式(24) はこの $\sigma_{m h}$ から求まる耐力を $Q_{F 2}$ とした式である.

表 3 に限界距離を満たさない試験体について $Q_{c}, Q_{F 1}, Q_{F 2}$ の值を 基準耐力 $Q_{a}$ で無次元化して示寸. $Q_{F 1}$ の括弧内の值は近似前の式に よる結果であり, 近似後もほぼ変わらない. 弾性限耐力 $Q_{c}$ は現行の 構造計算で用いられる耐力の最小值である $Q_{a}$ の 6 割以下となり, ど こも塑性化しないというのはかなり厳しい条件であることが分かる。 許容耐力 $Q_{F 1}, Q_{F 2}$ については $Q_{F 2}$ が 1 割程度高めの結果となってい る. 応力集中を考えずに容易に計算できるのは良いが，限界距離を 満たさずに $Q_{p}$ が確保できない場合であることを考えれば, 確実に安 全側である $Q_{F 1}$ の方が有効であると思われる. 


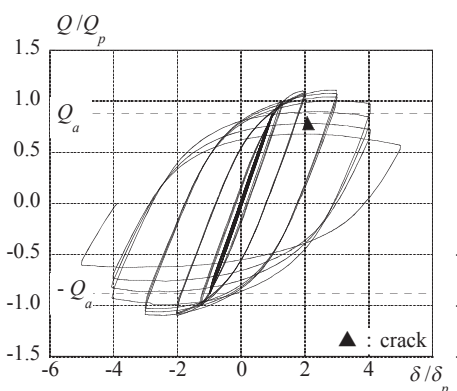

(a) $\mathrm{H} 1$

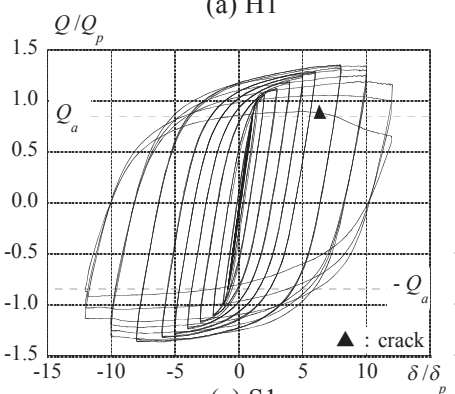

(e) $\mathrm{S} 1$

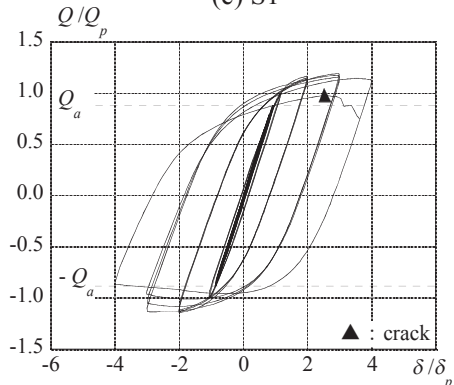

(i) $\mathrm{H} 5$

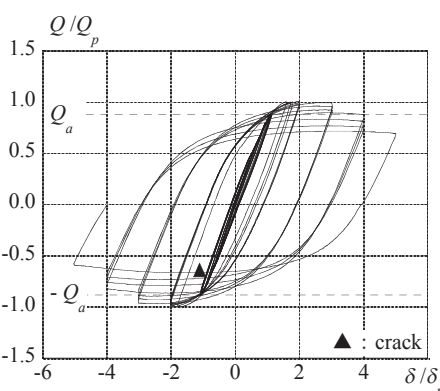

(b) $\mathrm{H} 2$

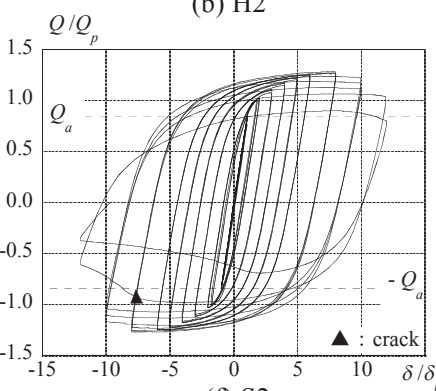

(f) $\mathrm{S} 2$

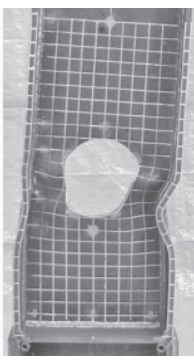

(a) $\mathrm{H} 1$

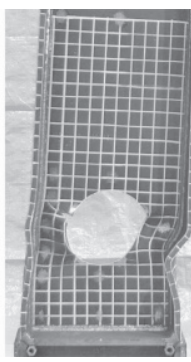

(b) $\mathrm{H} 2$

図 18 荷重変位関係

\section{4. 高強度鋼有孔梁の大変形挙動と最終崩壊形式}

本論文では高強度鋼を用いた場合の孔周辺の応力分布と許容耐力 の関係を示すのが主要な目的であるが, その後の大変形挙動につい ても貴重な資料になると思われるため，ここに掲載する.

図 18 に耐力が劣化するまでの全試験体の繰返し履歴を示す.縦軸 は全塑性耐力 $Q_{p}$, 横軸は孔によるせん断変形を考慮しない $\delta_{p}$ で無次 元化している. 縦軸の目盛の值は全試験体で同じ大きさにし, 横軸 は H-SA700 試験体と SN400 試験体で異なる. 写真は載荷終了後の 様子である，写真より試験体(a)H1，(b)H2，(c)H3 の崩壊形式はウェ ブのせん断変形に引き込まれることでフランジが大きく変形したも のである. 写真(d)H4 はウェブが大きくせん断変形し, フランジが ウェブに引き込まれる前に孔縁のき裂が進展して耐力劣化している. この崩壊形式は試験体 S4 でも同じで, 図 18(h)S4 より他の有孔試験 体より明らかに早く耐力劣化する．H4，S4 はウェブが薄い，せん 断降伏先行の試験体であるためと考えられる.

以下では個々に H-SA700 試験体について基準試験体及び SN400 試験体との比較を行う.

基準試験体の(a)H1 は $Q_{p}$ を確保した後, $2 \delta_{p}$ で繰返しによる耐力低 下を起こしたが, 孔周りでウェブの平面保持が崩れはじめた $3 \delta_{p}$ で 最大耐力となっている. つまり $2 \delta_{p}$ の繰返しによる耐力低下は高強 度鋼の局所的塑性化による変位増加と同様のことと考えられる. そ の後 $4 \delta_{p}$ の 3 周目でウェブとフランジの接合部周辺にき裂が入り, そのき裂が拡がることで耐力劣化していった．SN400の(e)S1 は $Q_{p}$
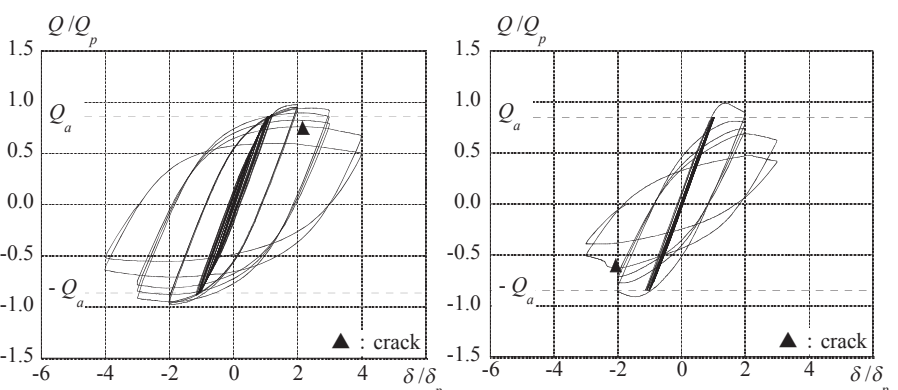

(c) $\mathrm{H} 3$
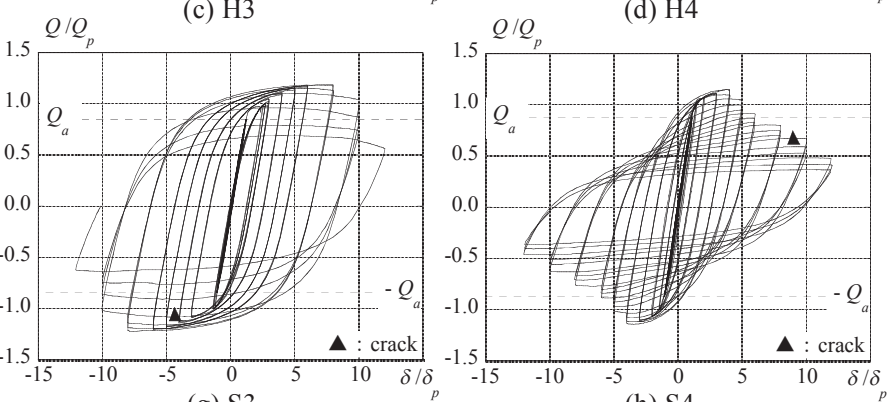

(g) S3

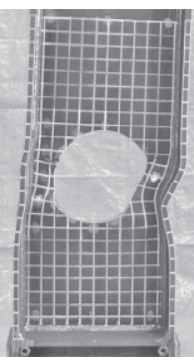

(c) $\mathrm{H} 3$

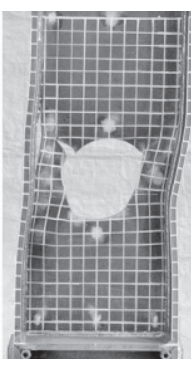

(d) $\mathrm{H} 4$

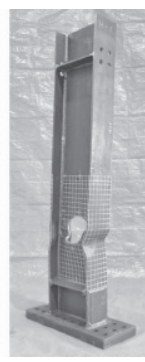

(e) $\mathrm{H} 1$ 全体 (h) S4

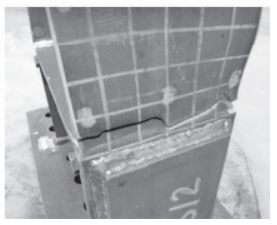

(f) H5 梁端部き裂
写真 1 載荷後の様子

を確保した後もひずみ硬化により耐力は上昇する，最大耐力までの 繰返しによる耐力低下はないが，き裂進展後の耐力劣化は H1 より も顕著である.

孔位置が端部に近い試験体(b)H2 は $Q_{p}$ がほぼ最大耐力となった. これに対して(f)S2 は $Q_{p}$ を十分確保している. その後 $\mathrm{H} 2$ は繰返すご との耐力低下はあるが, ループ内で耐力はあまり低下せず， $5 \delta_{p}$ のル 一プで孔縁にき裂を確認した.き裂発生以降の履歴はH1 と同様に,

H2 は S2 より緩やかに耐力劣化する.

孔径の大きな試験体 $(\mathrm{c}) \mathrm{H} 3$ は $Q_{p}$ を確保できずに最大耐力をむかえ た。これに対して $(\mathrm{g}) \mathrm{S} 3$ は $Q_{p}$ を確保している. $\mathrm{H} 3$ は $4 \delta_{p}$ で孔縁とウ エブとフランジの接合部の両方にき裂が入り, 耐力劣化した. S3 は 孔縁にき裂前のしわは見られたが，ウェブとフランジの接合部で先 にき裂が進展し，耐力劣化した．ただし S3 は S1，S2 のようなき裂 発生以降の明らかな耐力劣化は見られなかった。

ここで加藤らの限界距離9) と全塑性耐力 $Q_{p}$ の確保について考える. 本研究で H2，H3，S2，S3 は限界距離を満たしておらず， $Q_{p}$ を確保 できないと考えられた試験体である。しかし，本実験では $\mathrm{H} 2$ は $Q_{p}$ の確保があいまいで，H3 は確保できず，S2, S3 は十分確保できる 結果となった。つまり加藤らの限界距離は普通鋼では少し安全側に 余裕度を持っており, 高強度鋼 H-SA700のような降伏比が高い場合 でも十分当てはまると考えてよい.

ウェブが薄い試験体の $(\mathrm{d}) \mathrm{H} 4$ も $\mathrm{H} 3$ と同様に $Q_{p}$ を確保できずに最 大耐力をむかえた. (h)S4 は $Q_{p}$ を確保している. H4 はウェブの面外 
への変形が大きいため, 耐力劣化が早く, $3 \delta_{p}$ のループ途中で孔縁 にき裂が入った.その後ウェブとフランジの接合部にもき裂が入り， 殆ど力を負担しない履歴となった. S4 の最終状態は両側のフランジ がウェブの変形に引き込まれた状態であった. 最大耐力以降, 繰返 しによる耐力低下と変形が大きくなることによる耐力劣化により, 耐力を負担しない横長の履歴になった. しかしループ途中での耐力 低下やき裂発生以降の急激な耐力劣化はみられなかった。

無孔試験体の(i)H5 は $Q_{p}$ を確保した後, フランジが局部座屈し, その後, 梁端部のスチフナ溶接部でき裂が発生し, 衝撃音とともに フランジに写真の(f)H5 のようなき裂が生じた. 耐力は急激に劣化し, 変位計による測定は出来なかったため, 図 18(f) は急激な耐力劣化前 までである.H-SA700 のような高強度鋼材の脆性的な破断について は特に注意が必要であり, どのように崩壊し, どこにき裂が入るこ とで耐力劣化していくのかを明らかにすることは重要である. 本研 究のように梁端部での崩壊にならない有孔梁を用いることは脆性的 な破断を予防する一つの手段になりうると考えられる.

\section{5. 結}

本論文は高強度鋼を用いた有孔梁の繰返し載荷実験を行い，従来 鋼と異なる高強度鋼の特性を確認した。 孔周りの局所的塑性化が全 体挙動に与える影響を明らかにし, 応力集中を考慮した許容耐力を 提案した. 最後に大変形挙動についても言及した. 以下に得られた 知見をまとめて示す.

1）高強度鋼を用いた様々な有孔梁と無孔梁について現行の設計で 用いられる弾性耐力で曲げせん断繰返し載荷を行った。無孔梁 の全体挙動は梁端部降伏耐力の 0.9 倍まで概ね線形挙動であり, 1.0 倍の繰返しで, 変形が増加していく高強度鋼の特性を示した. この特性は著者らの前実験における帯板の引張圧縮挙動時 ${ }^{8)}$ で も確認されている.

2）有孔梁について孔周りでの局所的塑性化が高強度鋼の全体挙動 における変形増加を増幅することを指摘した．加藤ら ${ }^{9}$ が提示 した，孔周辺での損傷より前に梁端部が全塑性耐力を確保でき る孔位置, 限界距離を満たさない試験体 H2, H3, H4 は特にそ の増幅が顕著である。

3）高強度鋼の有孔梁について変位増加の特性を考慮した許容降伏 耐力を提案した. 無孔梁の許容耐力を梁端部降伏耐力の 0.9 倍と し，有孔梁は限界距離を満たす場合について無孔梁と同様の耐 力とした，満たさない場合については応力集中を考慮した耐力 $Q_{c}, Q_{F}$ を新たに提案した.

4） $Q_{c}$ はいずれの部分も降伏していない有孔梁の弾性限耐力である. 曲げせん断力が作用する場合に最も応力集中が起きる孔縁につ いて，等曲げと純せん断状態の弾性理論から近似的に応力度を 求めることから算出した. 本実験の範囲では $Q_{c}$ は現行の設計で 用いられる弾性耐力の 6 割以下の耐力となった.

5） $Q_{F}$ は全体挙動が変位増加を起こさず, 線形挙動となる耐力であ る. 最小断面の応力度分布から求められ, 応力集中係数を安全 側に考慮した耐力 $Q_{F 1}$ を求めた。本実験の限界距離を満たさな
い試験体は現行の設計で用いられる弾性耐力の $0.67 \sim 0.82$ 倍で ある。

6) 大変形挙動時に有孔梁の繰返し履歴は孔周りの平面保持が崩れ るまで耐力が上昇し，き裂が入るまで安定した挙動をすること を示した，高強度鋼においても孔周辺でのき裂であれば脆性的 な破断とはならず, 急激な耐力劣化とならないことを確認した。

\section{参考文献}

1) 日本建築学会構造委員会鋼構造運営委員会 : 鋼構造による新構造システ ム開発の現状と今後の展望, 2009 年度日本建築学会大会(東北), 構造部 門(鋼構造)，パネルディスカッション資料，2009.8

2）塩飽豊明, 吉田譲, 崎山哲雄, 福田多一郎: 建築構造用高強度 $800 \mathrm{~N} / \mathrm{mm}^{2}$ 級鋼の機械的性質, 日本建築学会大会学術講演梗概集(中国), C- 1, 構 造 III，PP613-614，2008.9

3）竹内徹, 松井良太, 大山翔也, 石原直: 制振部材を付加した高強度架構 の繰返し変形性能-制振部材を付加した高強度架構の耐震性能 その1-そ の 2, 日本建築学会構造系論文集, Vol.75, 第 655 号, pp1671-1679, 2010.9, Vol.76, 第 661 号, pp695-702, 2011.3

4）木村祥裕，篠崎真一，石原直：高強度鋼ダイアフラムレス型柱梁部分架 構の損傷過程と力学性能評価, 日本建築学会構造系論文集, Vol.75, 第 658 号, pp2221-2230, 2010.12

5）玉井宏章, 松尾彰, 山西央朗, 高松隆夫: 建築構造用高強度鋼材 H-SA700A を用いた乾式組立材の弾性横座屈耐力評価式に関する一考察, 日本建築 学会構造系論文集, Vol.76, 第 659 号, pp157-165, 2011.1

6）玉井宏章, 山西央朗, 高松隆夫, 松尾彰:建築構造用高強度鋼材 H-SA700A を用いた乾式組立材の横座屈性状に関する実験的研究, 日本建築学会構 造系論文集, Vol.76，第 660 号, pp407-416, 2011.2

7）五十嵐規矩夫，末国良太，王蓞：高強度鋼を用いたウェブ幅厚比の大き な H 形断面梁の繰返し挙動, 日本鋼構造協会 鋼構造年次論文集, 第 17 巻, pp541-548, 2009.11

8）五十嵐規矩夫，石原直，井畔文彦：単軸繰返し荷重を受ける円孔付き高 強度鋼板の力学性状, 日本鋼構造協会 鋼構造年次論文集, 第 18 巻, pp225-230, 2010.11

9）加藤勉，金子洋文：鉄骨梁貫通孔の梁端からの限界距離について，日本 建築学会構造系論文集, 第 496 号, pp105-112, 1997.6

10）福知保長, 土井康生, 細川裕司 : 円形孔を有するはりの耐力と設計法 1 . 無補強の場合の耐力, 日本建築学会論文報告集，第 296 号, pp27-36, 1980.10

11）西田正孝：応力集中（増補版），森北出版，pp224 227，pp253 257， pp265 271, 1973.12

12）若林實：鉄骨構造学詳論，丸善，pp238 240, 1985.2

13) Z.Tuzi : Effect of a Circular Hole on the Stress Distribution in a Beam under Uniform Bending Moment, Phil mag., ser.7, Vol.9(Feb.1930), pp210 223

14）後藤恵之輔：孔をもつ有限板の二次元弾性問題の一解法，土木学会論文 報告集，第 234 号，pp11 22，1975.2

15) J.E.Bower: Elastic Stresses around Holes in Wide-Flange Beams, J.Str, Div. ASCE, Vol.92, No.ST2, pp85-101, 1966.4

16) J.E.Bower : Experimental Stresses around Holes in Wide-Flange Beams with Holes, J.Str, Div., ASCE, Vol.92, No.ST5, pp167-186, 1966.10

17) G.B.Jeffery, Phil. Tians. Roy. Soc., London, Vol.A.221, pp265-293, 1921

18）鴉戸口英善: 双極座標による二・三の平面弾性問題の解(その 3-その 4), 機械学会論文集，第 15 巻, No. I, pp.76 97, 1949

19) R.C.J.Howland, Phil. Tians. Roy. Soc., London, Vol.A.229, pp49-86, 1930

20) R.C.J.Howland, Phil. Tians. Roy. Soc., London, Vol.A.232, pp155-222, 1933

21）五十嵐規矩夫，鈴木玩也：円形開口を有する $\mathrm{H}$ 形鋼梁のせん断力伝達機 構, 日本建築学会大会学術講演梗概集（北陸），C-1，PP.489-450，2002.8

（2011年 8 月 10 日原稿受理，2012年 1 月20日採用決定） 